\title{
EDGE EFFECTS ON UNDERSTORY EPIPHYTIC FERNS AND EPIPHYLLOUS BRYOPHYTES IN MOIST AFROMONTANE FORESTS OF ETHIOPIA
}

\author{
KRISTOFFER HYLANDER ${ }^{1}$, SiLESHI NEMOMISSA \& WOLDEYOHANNES ENKOSA
}

\begin{abstract}
Most studies on edge effects in tropical forests have been conducted in landscapes with low human population density and in situations where the edges have been left unused after logging of the adjacent area. Here we studied forest margins heavily used by local farmers in a forest/agriculture mosaic landscape in Ethiopia. We compared forest structure and plant species composition across 41 forest-agriculture ecotones from $200 \mathrm{~m}$ out into the agricultural area to $200 \mathrm{~m}$ into the forest. There are strong edge effects from the edge and into the forest on canopy cover and number of stumps and apparently these forest-agricultural edges are intensively used by humans. They are penetrated by paths, beehives are found in the trees, timber of various dimensions is harvested and there is sometimes substantial cover of perennial wild (or semi-wild) crops such as coffee and spices. The number of understory epiphytic fern species as well as number of epiphyllous (i.e., growing on leaves) bryophyte species was lower at $20 \mathrm{~m}$ than at $75 \mathrm{~m}$ from the edge. The number of fern species was higher in newly created edges and thereafter they declined, which indicates an extinction debt. This pattern was not seen for the epiphyllous bryophytes. It is likely that different human management activities are responsible for many of the found edge effects besides wind and sun effects from the edge. Tropical forest margins provide important resources for people in many landscapes. It is important to understand how such use affects the biota of the forests. This study shows that there are substantial edge effects, but that the edge effects do not seem to become worse over time for epiphyllous bryophytes and only slightly so for ferns.
\end{abstract}

Key words: Afromontane forests, bryophyte, ecotone, edge effects, epiphyte, extinction debt, fern, microclimate

Kristoffer Hylander, Department of Ecology, Environment and Plant Sciences, Stockholm University, SE-106 91 Stockholm, Sweden; e-mail: kristoffer.hylander@su.se

Sileshi Nemomissa, Department of Plant Biology \& Biodiversity Management, Addis Ababa University, P.O. Box 3434, Addis Ababa, Ethiopia

Woldeyohannes Enkosa, Department of Biology, Nekemte College of Teachers Education, P.O. Box 88, Oromia, Ethiopia

\section{INTRODUCTION}

Edge effects are one important aspect of forest fragmentation that could negatively influence forest specialist species (Murcia 1995; Harper et al. 2005). However, the effect of edge creation can differ much depending on which type of edge it is, if it is a permanent shift in land use outside the forest edge, if the edges are utilized for something, which type of forest that is affected, etc. (Ries et al. 2004; Harper et al. 2005). When developing an understanding of conservation options and obstacles there is a need to study what drives edge creation, how people utilize edges, as well as how forest organisms are responding

\footnotetext{
1 Corresponding author
}

to the edges (Tschantke et al. 2007). It is in the margins that the human utilization of forest products is highest and the activities in the margin can guide predictions regarding future overall changes in forest cover and forest integrity in that region (Hylander et al. 2013).

Many studies of tropical forest margins have been conducted in moist forests that have been subjected to timber harvesting and where either new forests have been regenerated or when largescale cattle ranges have replaced the forests. Such edges have been left and in many cases sealed with vines and lianas after a while, making microclimatic edge effects limited after some years (Murcia 1995; Camargo \& Kapos 1995; Didham 
\& Lawton 1999). The extent to which the results from these studies are also representative of tropical edges in heavily populated landscapes is less clear. Forest margins in SW Ethiopia, which is the focus of this study, represent another type of margins which are heavily utilized by the agrarian population living adjacent to the forests. Generally the forest resources in Ethiopia are threatened (Teketay et al. 2010). The pattern in our investigated area is that annual crop agriculture has expanded into the forests at many places since the late 1960s (from when we have access to aerial photos), causing a $59 \%$ to $45 \%$ reduction in forest/ canopy cover (Hylander et al. 2013). The whole landscape can be characterized as a forest agricultural mosaic landscape and forest agriculture edges are found throughout the landscape (Hylander et al. 2013).

Epiphytic plants include vascular plants and bryophytes. Lichens are also commonly found growing epiphytically. Bryophytes have been pointed out as sensitive to alteration of forest habitats and have been evaluated as possible indicators of forest integrity (e.g., Frego 2007; Daniels et al. 2007), but epiphytic ferns and orchids have also been shown to display turnover along a disturbance gradient (Barthlott et al. 2001; Hundera et al. 2013). Changes in microclimate, which is reported to become altered by different management interventions in forest landscapes, have been suggested as one reason for these patterns (e.g., Patiño et al. 2009; Löbel et al. 2012; Sonnleitner et al. 2009). Both bryophytes and vascular epiphytic plants are thus good candidates for studies on edge effects. In some studies on edge effects on bryophytes from boreal forests, reduction in the occupancy of liverworts and growth of mosses has been recorded at 30 to $50 \mathrm{~m}$ into the forest (Moen \& Jonsson 2003; Hylander 2005; Löbel et al. 2012). However, studies from South Africa did not find any clear edge effects on mosses or liverworts (Hylander \& Hedderson 2007). A few studies have also been conducted on epiphyllous bryophytes (bryophytes growing on leaves of different plants) in tropical lowland rain forest in Amazonia. The results from these studies indicate that the edge effects are rather shallow, around
20-30 m, while isolation and the effects of reduced habitat area have had a dramatically negative effect on the epiphyll communities (Zartman \& Nascimento 2006; Zartman \& Shaw 2006). Edge effects on epiphyllous bryophytes have been little studied but it has been pointed out that even subtle microclimatic variation can structure epiphyllous bryophyte communities and that they could be very sensitive to forest alterations (Pócs 1996; Sonnleitner et al. 2009). More studies from tropical forests are needed to determine whether the edge effects are shallower in such settings (also cf. Silva \& Pôrto 2010).

Knowledge of the bryophyte distribution and ecology in the Ethiopian moist Afromontane forests is very limited. However, it has recently come to light that the flora is species rich, with many epiphyllous species in need of a moist microclimate (Hylander et al. 2010; Nemomissa et al. unpubl.). The local species richness of all bryophytes taken together is often around 65 species in $200 \mathrm{~m}^{2}$ plots in the forest when some canopy-living species are also taken into account (Hylander \& Nemomissa 2008, 2009).

In this study we asked how the forest structure and species composition of ferns and epiphyllous bryophytes looked in edges across the ecotone between agriculture and forest in Ethiopian moist Afromontane forests. We inventoried 41 such edges and analyzed how the edge effects differed between ferns and epiphyllous bryophytes and among edges that differed in age since they were created and in disturbance level.

\section{MATERIAL AND METHODS}

\section{STUDY AREA}

We conducted our study in a variegated landscape surrounding the town of Bonga in SW Ethiopia in the SNNPR Regional State (SW of Jimma, $7^{\circ} 11^{\prime}-7^{\circ} 27^{\prime} \mathrm{N}$, $36^{\circ} 06^{\prime}-36^{\circ} 22^{\prime} \mathrm{E}$, Fig. 1). The forest belong to the moist Afromontane type with mostly evergreen trees 10-40 m high, such as Sapium ellipticum (Hochst) Pax, Syzygium guineense DC., Schefflera abyssinica Harms and Olea welwitschii Gilg \& Schellenb. (Friis et al. 2010; Schmitt et al. 2010). The landscape is undulating with altitude varying from 1400 to $2500 \mathrm{~m}$ a.s.l. Rainfall in the area 

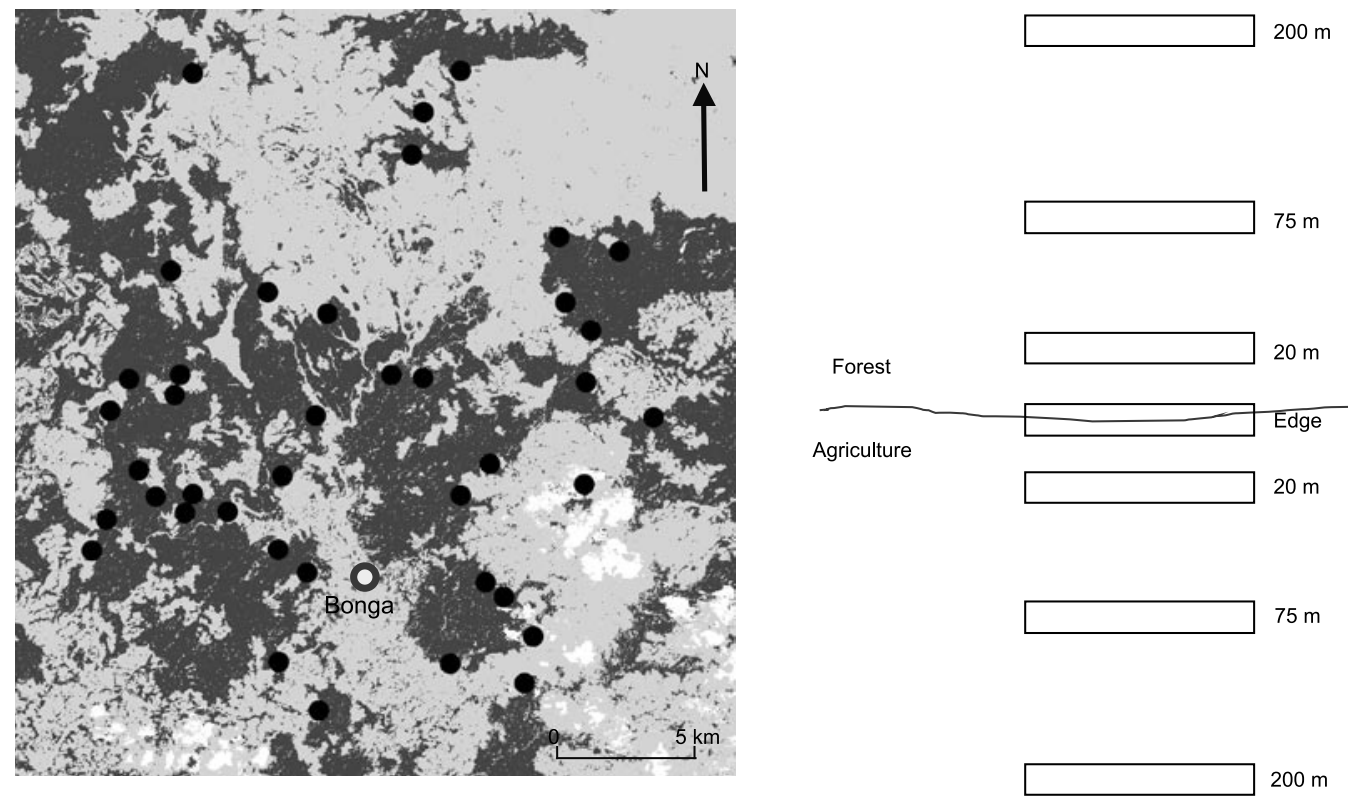

Fig. 1. Map of the study area surrounding the town of Bonga, indicating all studied edges (left) and the sampling design (right). Dark grey denotes forest (including coffee-growing semi-forest areas), light grey denotes agriculture (or wetlands in a few cases), and white areas were covered by clouds in this particular picture. The map is produced from a 2006 LANDSAT image.

is $c a 1800 \mathrm{~mm}$ spread out over the year but highest in the rainy season between June and September, and annual mean temperature is $c a 19^{\circ} \mathrm{C}$ (Schmitt 2006). The farming community grows maize and teff (Eragrostis tef Trotter) in open fields and various vegetables in their gardens. Coffee (Coffea arabica L.) is grown in forest margins, deeper into the forests, in small patches or under single shade trees in the home gardens, and is an important crop both for home consumption and for cash (Hylander \& Nemomissa 2008; Schmitt et al. 2010). It is not possible in satellite images to differentiate between natural forests and canopies with dense coffee production below. There is often a gradient between areas with much and little coffee in the understory. Other non-timber products such as honey and spices are also harvested from the forests (Gobeze et al. 2009).

\section{STUDY DESIGN}

\section{AND FOREST MARGIN INVENTORY}

On a Landsat image from 2006 complemented with an image from 2008 we selected 41 edges between agriculture and forests (USGS 2008, http://www.usgs.gov). By looking at old aerial photos from late 1960s and five Landsat images in between (differing 5-10 years between images) we could get a rough estimate of the age of each forest edge. Around half of the sites had stable edges for the last 40 years.

At each site we laid out transect plots (50 m long) along the forest/agricultural edge. Additionally we established three transect plots in the forest and three in the agricultural area at the following distances from (and parallel to) the edge transect: $20 \mathrm{~m}, 75 \mathrm{~m}$ and $200 \mathrm{~m}$ (Fig. 1). Altogether we thus collected data from seven transect plots at each site.

Each transect was $10 \mathrm{~m}$ wide and was divided into 5 subplots $(10 \times 10 \mathrm{~m})$ in which the following variables were visually estimated: canopy cover $(\%)$, cover of shrubs $(\%)$, cover of vines $(\%)$, cover of understory $(\%)$ and cover of coffee $(\%)$. We recorded the average height of coffee plants (m), average diameter of coffee plants $(\mathrm{cm})$, frequency of prunings $(0,1=$ few, $2=$ many, $3=$ all) and the cover (visually estimated) of the spices Afromomum corrorima (Braun) P. C. M. Jansen (\%) and Piper capense L. (\%). We recorded the presence of beehives in trees, the number of recent large stumps $(<10$ years since cutting) and the number of recent small stumps $(<10$ years since cutting). We recorded the number of human paths crossing the transect, the cover (visually estimated) of bryophytes (\%) on the base $0-3 \mathrm{~m}$ ) of the tree trunk ( $>20 \mathrm{~cm}$ thick) most central in the transect, and the cover of various annual 
crops. All tree species were identified to species and their circumference was measured with a measuring tape. In a narrower transect ( $5 \mathrm{~m}$ wide) we inventoried all epiphytic fern species found on tree trunks and shrubs up to $4 \mathrm{~m}$ from the ground along each $10 \mathrm{~m}$ stretch of the transect. This gave a frequency value of $0-5$ for each species in each transect. In these narrower transects we also collected epiphyllous bryophytes for later identification in the lab.

The fieldwork was conducted between October 12, 2008 and April 10, 2009.

\section{STATISTICAL ANALYSES}

We evaluated the edge effects for the different response variables using mixed effect modeling using the lme4-package in the $\mathrm{R}$ program (Anonymous 2010). For number of ferns we used a Poisson distribution and for the rest of the variables a Gaussian distribution. We included site as a random factor and the different transect plot locations (the seven different locations at different distances from the edge) as the main explanatory variable. The differences among the distances were evaluated using the multicomp package. We ran linear models (for epiphyllous species) and general linear models with a Poisson distribution (for ferns) to assess whether the magnitude of the edge effect in the edge plot and $20 \mathrm{~m}$ into the forest varied as a function of edge age and disturbance level (number of stumps and canopy cover). Possible deviations from model assumptions were evaluated by inspection of residual plots.

\section{RESULTS}

The number of stumps was highest in the edge plot followed by the transect plot at $20 \mathrm{~m}$ into the forest, and declining towards both the agricultural areas and into the forest (Fig. 2). We found distinct edge effects for canopy cover and even more so for bryophyte cover $(\mathrm{p}<0.001$, general and linear mixed effect models) (Fig. 2).

The number of epiphytic understory fern species decreased significantly towards the forest-agricultural edge (Fig. 3). On average 7-8 species were found in a $250 \mathrm{~m}^{2}$ transect plot at 75 and $200 \mathrm{~m}$
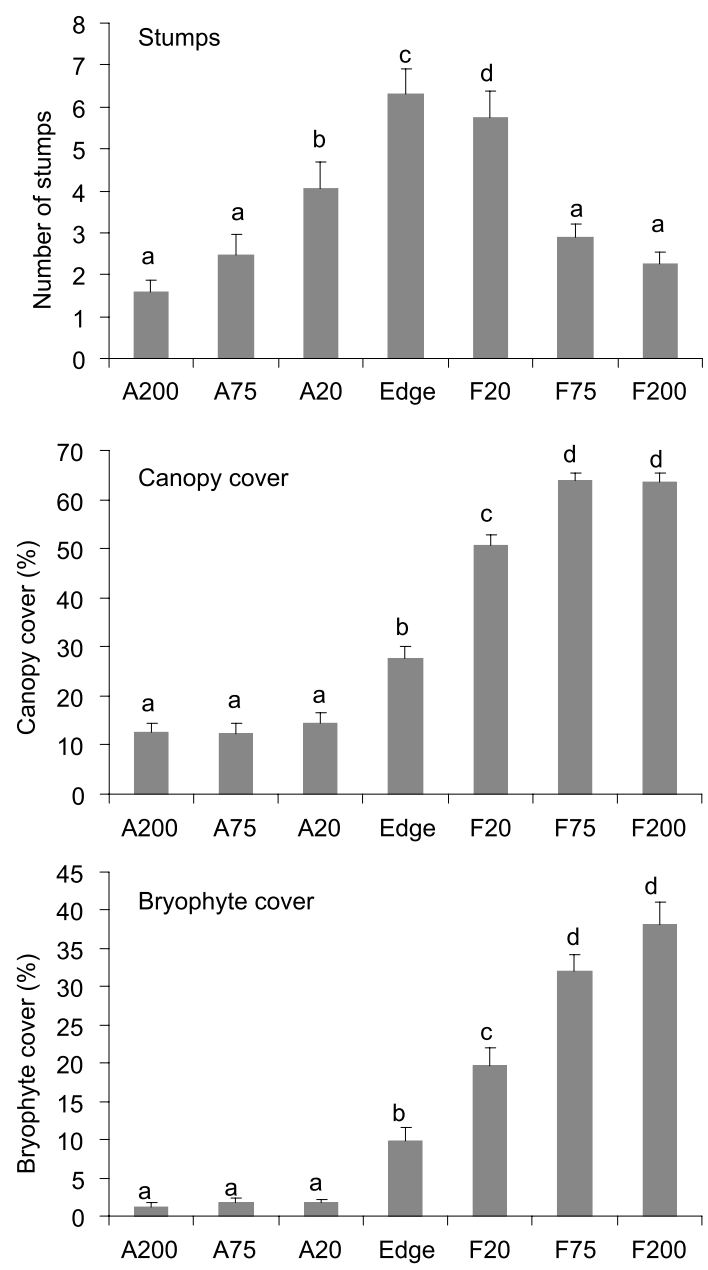

Fig. 2. Effects of edges on number of stumps $>10 \mathrm{~cm}$ diameter, canopy cover and bryophyte cover on the base of stems across 41 agriculture/forest ecotones at the forest-agricultural edge and at different distances (meters) into agriculture (A) and forest (F) from that edge. Lowercase letters denote significant differences after multiple comparisons after mixed effect models (see methods).

into the forest, while only 3 species were found in the edge plot. In the agricultural landscape a few ferns were found on the remaining trees, but these were found mostly on rather recently converted edges (analysis not shown). The number of species of ferns in the edge plot decreased significantly with time since conversion (GLM, $\mathrm{p}<0.001$ ). It also increased with increased canopy cover (in both the edge plot and the $20 \mathrm{~m}$ plot, $\mathrm{p}<0.001$ and 
$\mathrm{p}=0.027)$, and decreased with number of stumps in the $20 \mathrm{~m}$ transect plot $(\mathrm{p}=0.0025)$.

The number of epiphyllous bryophyte species also decreased markedly towards the edge from $\mathrm{ca}$ 9 species at $200 \mathrm{~m}$ into the forest to less than 2 in a transect plot at the edge (Fig. 3). The difference between the two interior plots was not significant, however. No epiphyllous species were found on the agricultural side of the forest-agricultural edge.

The number of epiphyllous species at the edge could not be explained by either edge age, canopy cover or number of stumps, but at $20 \mathrm{~m}$ into the forest the number of species was higher at sites with higher canopy cover $(\mathrm{p}=0.040)$.

Altogether we recorded 20 taxa of ferns (including two club mosses) ranging from 0 to 13 species in a single transect plot, and 46 epiphyllous bryophyte taxa ranging from 0 to 24 species in a single transect plot. There were no species of ferns or epiphyllous bryophytes showing a preference for edges versus forest interior (Tables $1 \& 2$ ).
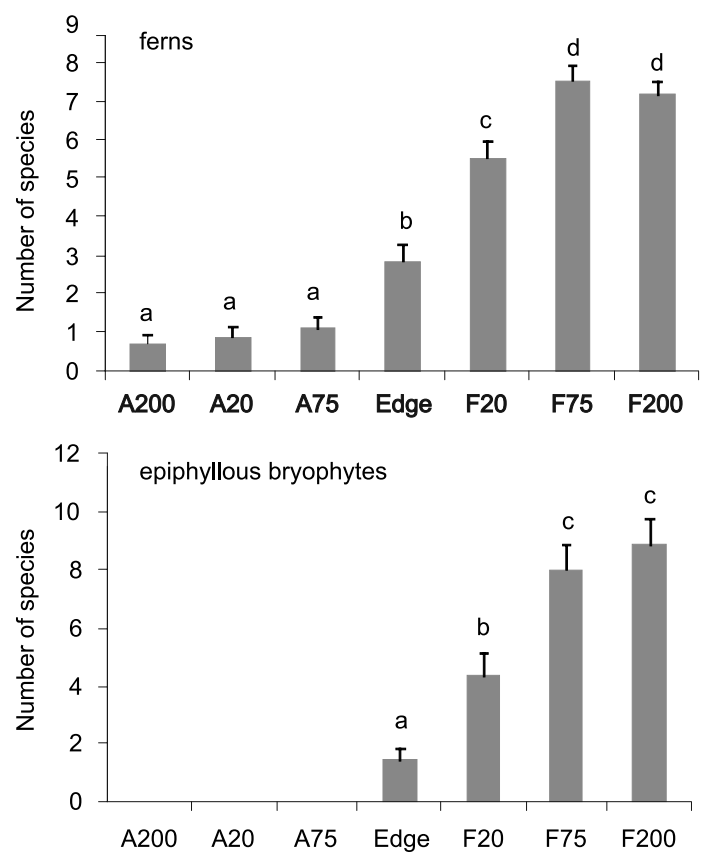

Fig. 3. Number of species of ferns and epiphyllous bryophytes in $50 \times 5 \mathrm{~m}$ plots at the forest-agricultural edge and at different distances (meters) into agriculture (A) and forest (F) from that edge. Lowercase letters denote significant differences after multiple comparisons after mixed effect models (see methods).

\section{DISCUSSION}

We found clear edge effects on a large variety of variables in the investigated moist Afromontane forest margins. Bryophytes have been suggested as good indicators of forest integrity and this was also supported by this study, since both bryophyte cover and species richness of epiphyllous bryophytes showed the deepest and strongest edge effects (cf. Figs $2 \& 3$ ). There was perhaps even a tendency of an edge effect beyond $75 \mathrm{~m}$ into the forests.

Edge effects in tropical forests have been suggested to be rather shallow because of edge sealing with lianas (Murcia 1995; Camargo \& Kapos 1995; Didham \& Lawton 1999). However, other authors have suggested that the edge effects could be very deep (Laurance 2000). Since we did not explore the edges deeper into the forests than $200 \mathrm{~m}$ (which then became our reference) we cannot say anything about edge effects much beyond $75 \mathrm{~m}$. It is clear, however, that edge effects in terms of human utilization are much deeper and probably most forested areas in this landscape are used in some ways by farmers. The extent to which this affects the growth conditions and species composition of ferns and epiphylls (or other groups of organisms) is less evident, and our study cannot shed light on that.

Epiphyllous species have fast population turnover, which makes them ideal for use in studies of environmental gradients and changes (Pócs 1977). Interesting things have been learned from Amazonia on the effects of fragmentation on these communities (e.g., Zartman \& Shaw 2006); the cited study showed that they are strongly dispersallimited but that the edge effects are not very pronounced. Our study stands in contrast, in that there was a very strong edge effect, most likely driven by microclimatic gradients, since bryophyte cover on the trunks was also clearly affected (cf. Sonnleitner et al. 2009). One possible explanation might be that our edges were managed by people who regularly did selective logging and various clearance activities, thus maintaining a dryer microclimate. This was also supported by the inclusion of both canopy cover and number of stumps as explanatory 
Table 1. Fern species (and clubmosses) found in 41 forest margins in Bonga, SW Ethiopia. At each site species were recorded at different distances (meters) into agriculture (A) and into forest (F) from that edge (Fig 1). The figures thus denote how many times a species was recorded at a given distance for all 41 forest margins (e.g., Arthopteris monocarpa was recorded at two sites at $75 \mathrm{~m}$ into the agricultural area but at nine sites at $200 \mathrm{~m}$ into the forest).

\begin{tabular}{l|c|c|c|c|c|c|c}
\hline Species & A200 & A75 & A20 & Edge & F20 & F75 & F200 \\
\hline Arthopteris monocarpa (Cordem.) C. Chr. & 0 & 2 & 0 & 2 & 4 & 9 & 9 \\
Arthopteris orientalis (Cordem.) C. Chr. & 1 & 2 & 3 & 1 & 6 & 4 & 5 \\
Asplenium aethiopicum (Burm. f.) Bech. & 1 & 1 & 1 & 1 & 7 & 7 & 3 \\
Asplenium bugoiense Hieron & 0 & 0 & 0 & 0 & 4 & 16 & 11 \\
Asplenium ceii Pic. Serm. & 0 & 0 & 0 & 0 & 1 & 1 & 6 \\
Asplenium protensum Schrad. & 0 & 0 & 0 & 0 & 0 & 0 & 1 \\
Asplenium smedsii Pic. Serm. & 0 & 0 & 0 & 0 & 0 & 2 & 1 \\
Asplenium erectum Bory ex Willd. & 0 & 0 & 1 & 1 & 0 & 5 & 2 \\
Asplenium manii Hook. & 0 & 0 & 0 & 2 & 3 & 12 & 12 \\
Asplenium sandersonii Hook. & 0 & 0 & 1 & 5 & 20 & 33 & 33 \\
Asplenium theciferum (Humb., Bonpl. \& Kunth) Mett. & 0 & 1 & 2 & 2 & 3 & 2 & 5 \\
Crepidomanes melanotrichum (Schltdl.) J. P. Roux & 0 & 0 & 0 & 1 & 2 & 3 & 4 \\
Drynaria volkensii Hieron. & 0 & 1 & 5 & 3 & 13 & 9 & 15 \\
Huperzia dacrydioides (Baker) Pic. Serm. & 0 & 1 & 0 & 2 & 2 & 0 & 0 \\
Lepisorus excavatus (Wild.) H. Ohba & 0 & 0 & 1 & 0 & 3 & 2 & 0 \\
Loxogramme abysinica (Baker) M. G. Price & 0 & 0 & 0 & 3 & 11 & 24 & 17 \\
Oleandra distenta Kunze & 0 & 0 & 0 & 0 & 0 & 1 & 1 \\
Pleopeltis macrocarpa (Wild.) Kaulf & 0 & 1 & 1 & 5 & 8 & 13 & 6 \\
Selaginella sp. & 0 & 0 & 0 & 0 & 1 & 0 & 0 \\
Vittaria volkensii Hieron. & 0 & 0 & 0 & 0 & 2 & 6 & 6 \\
\hline
\end{tabular}

variables in some models. Results similar to ours have been reported from dry forests in the tropical Andes (Werner \& Gradstein 2009).

The relaxation time (time to extinction) in the edges was longer for ferns than for epiphyllous bryophytes, probably due to the shorter life cycles of these species (cf. Hylander \& Ehrlén 2013). Otherwise it seemed that the edges were rather similar over time and there was no evidence of edge sealing, as has been suggested for other tropical edges (e.g., Camargo \& Kapos 1995; Didham \& Lawton 1999).

No species of ferns or epiphyllous bryophytes showed a preference for edge or agricultural areas, although some species seemed to be more tolerant than others. Among the ferns, we found, for example, Artopteris orientalis, Asplenium theciferum and $A$. aetiopicum relatively frequently in exposed situations (Table 1). These species are also frequently encountered on exposed isolated trees in home gardens in the same landscape (Hylander
\& Nemomissa 2009). Among the epiphyllous species it is quite evident that the mosses are more tolerant than the liverworts to exposure at edges (Table 2). The large majority of mosses found on leaves are facultative epiphylls and normally are more frequent as epiphytic plants on the trunk or branches of trees and shrubs than as epiphylls. For the more strict epiphyllous species, such as most species in the genera Cololejeunea, Colura, Diplasiolejeunea, Odontolejeunea and Drepanoleunea, the edge effect was even more pronounced (Table 2).

We did not take into account soil moisture or the presence of streams in this study. Another study has shown that distance to streams is a strong regulator of the epiphyll community in this landscape (Nemomissa et al. unpubl.). If that factor had also been taken into account we could perhaps explain more of the variation between sites and between distances into the forest than we can with these data. 
Table 2. Epiphyllous species found in 41 forest margins in Bonga, SW Ethiopia. Number of records at each distance for all 41 forest margins is given in each column.

\begin{tabular}{|c|c|c|c|c|}
\hline Name & Edge & $20 \mathrm{~m}$ & $75 \mathrm{~m}$ & $200 \mathrm{~m}$ \\
\hline \multicolumn{5}{|l|}{ LIVERWORTS } \\
\hline Caudalejeunea sp. & 2 & 7 & 20 & 17 \\
\hline Cololejeunea apliculata (E. W. Jones) R. M. Schust. & 0 & 3 & 0 & 1 \\
\hline Cololejeunea cardiocarpa (Mont.) A. Evans & 7 & 15 & 27 & 26 \\
\hline Cololejeunea distalopapillata (E. W. Jones) R. M. Schust. & 2 & 11 & 21 & 23 \\
\hline Cololejeunea elegans Steph. & 0 & 0 & 0 & 1 \\
\hline Cololejeunea latilobula (Herzog) Tixier & 0 & 2 & 12 & 12 \\
\hline Cololejeunea minutissima (Nees \& Mont.) Schuster & 5 & 9 & 7 & 13 \\
\hline Cololejeunea nigerica (E. W. Jones) R. M. Schust. & 1 & 5 & 14 & 12 \\
\hline Cololejeunea obliqua (Nees \& Mont.) Schiffner & 0 & 1 & 2 & 4 \\
\hline Cololejeunea obtusifolia (E. W. Jones) Tixier & 7 & 20 & 34 & 31 \\
\hline Colura digitata (Mitt.) Steph. & 2 & 5 & 5 & 6 \\
\hline Colura tenuicornis (Mitt.) Steph. & 2 & 5 & 11 & 7 \\
\hline Diplasiolejeunea cornuta Steph. & 1 & 1 & 1 & 2 \\
\hline Diplasiolejeunea symoensii Vanden Berghen & 0 & 1 & 1 & 2 \\
\hline Drepanolejeunea cultrella (Mitt.) Steph. & 0 & 1 & 2 & 3 \\
\hline Drepanolejeunea symoensii Vanden Berghen \& Grolle & 0 & 2 & 6 & 5 \\
\hline Frullania $\mathrm{sp.}$ & 0 & 1 & 1 & 5 \\
\hline Lejeunea sp. & 6 & 18 & 31 & 29 \\
\hline Leptolejeunea asteroidea (Mitt.) Steph. & 0 & 0 & 0 & 2 \\
\hline Lophocolea $\mathrm{sp}$. & 0 & 0 & 1 & 2 \\
\hline Metzgeria sp. & 8 & 14 & 24 & 26 \\
\hline Microlejeunea africana Steph. & 6 & 18 & 20 & 23 \\
\hline Odontolejeunea lunulata (Web.) Schiffner & 1 & 7 & 12 & 13 \\
\hline Plagiochila sp. & 1 & 3 & 5 & 10 \\
\hline Ptychantus africanus Steph. & 0 & 0 & 2 & 2 \\
\hline Radula fulvifolia (Hook. f. \& Tayl.) Gottsche & 0 & 0 & 2 & 0 \\
\hline Radula quadrata Gottsche & 0 & 2 & 2 & 3 \\
\hline Radula voluta Taylor ex Gottsche & 0 & 0 & 0 & 1 \\
\hline Taxilejeunea conformis (Nees \& Mont.) Steph. & 1 & 8 & 9 & 11 \\
\hline
\end{tabular}

\section{MosSES}

Cryphaea sp.

Daltonia sp.

Entodontella cameruniae Broth.

Entodontopsis nitens (Mitt.) W. R. Buck \& Ireland

Erythrodontium sp.

Fabronia sp.

Floribundaria floribunda (Dozy \& Molk.) M. Fleisch.

Lepidopilium sp.

Orthotrichella pandurifolia (Müll. Hal.) W. R. Buck

Porotrichum elongatum (Welw. \& Duby) A. Gepp

Racopilium africanum Mitt.

Rhyncostegiella sp.

Schwetschkea sp.

Sematophyllum sp.

Splachnaceae (unidentified)

Wijkia sp.

Zygodon sp.

\begin{tabular}{|c|c|c|c}
1 & 2 & 8 & 8 \\
0 & 0 & 1 & 0 \\
0 & 1 & 0 & 3 \\
0 & 0 & 1 & 0 \\
0 & 0 & 1 & 0 \\
0 & 0 & 0 & 2 \\
2 & 5 & 19 & 20 \\
0 & 1 & 4 & 3 \\
0 & 3 & 6 & 9 \\
0 & 2 & 6 & 13 \\
0 & 0 & 0 & 1 \\
2 & 2 & 6 & 6 \\
0 & 0 & 0 & 1 \\
0 & 1 & 0 & 0 \\
0 & 1 & 1 & 0 \\
0 & 0 & 2 & 2 \\
0 & 0 & 0 & 1 \\
\hline
\end{tabular}




\section{CONCLUSIONS}

Forest/agricultural edges are heavily affected by edge effects of various kinds including cutting of trees, dry microclimate, increased number of paths, etc. We found that the general pattern was a distinct change in most measured variables from the inner transect plots ( 75 and $200 \mathrm{~m}$ into the forest) towards the edges. The bryophyte variables seemed to be the most affected. In fact, it is possible that even the $200 \mathrm{~m}$ samples are affected by the edge in the sense that these areas also are used by humans for various purposes including wood harvesting, coffee management and bee hive exploitation. It is thus also clear that forest margins are important for the people who use them for various products. If the edges are very valuable the conversion rates to annual crop agriculture can be lower there, for example when there is much coffee grown (Hylander et al. 2013). Hence, stable edges can serve as important buffers surrounding areas with interior forest conditions. Conservation strategies for the Afromontane forests of Ethiopia must consider the high value of these edges to the people who make use of them, the strength of edge effects on organisms, and the need for a multidisciplinary understanding of forest margins in order to reach goals of poverty reduction and biodiversity conservation (Tscharntke et al. 2007).

ACKNowledgements. We thank Teshome Legesse for field assistance. The study was financed by a grant from the Swedish International Development Cooperation Agency (to K.H.). We also thank Támas Pócs for identifying some species from this dataset and for his generous help determining and confirming numerous liverwort samples as we were becoming acquainted with the Ethiopian liverworts, and the anonymous reviewer for helpful remarks on the manuscript.

\section{REFERENCES}

ANONYMOUS 2010. R Develomment core team. A language and environment for statistical computing. R Foundation for Statistical Computing, Vienna.

Barthlott W., Schmit-Neuerburg V., Nieder J. \& ENGWALD S. 2001. Diversity and abundance of vascular epi- phytes: a comparison of secondary vegetation and primary montane rain forest in the Venezuelan Andes. Plant Ecology 152: 145-156.

Camargo J. L., \& Kapos V. 1995. Complex edge effects on soil moisture and microclimate in central Amazonian forest. J. Trop. Ecol. 11: 205-221.

DANIElS A. E. D. \& KARIYAPPA K. C. 2007. Bryophyte diversity along gradient of human disturbance in the southern Western Ghats. Curr. Sci. 93: 976-982.

DidHAM R. K. \& LAWTON J. H. 1999. Edge structure determines the magnitude of changes in microclimate and vegetation structure in tropical forest fragments. Biotropica 31: 17-30.

FREGO K. A. 2007. Bryophytes as potential indicators of forest integrity. Forest Ecology and Management 242: 65-75.

FRIIS I., DEMISSEW S. \& VAN BREUGEL P. 2010. The Atlas of potential vegetation of Ethiopia. Royal Academy of Science and Letters, Copenhagen.

Gobeze T., Bekele M., Lemenih M. \& Kassa H. 2009. Participatory forest management and its impacts on livelihoods and forest status: the case of Bonga forest in Ethiopia. International Forestry Review 11: 346-358.

Harper K. A, Macdonald S. E., Burton P. J., Chen J., Brosofske K. D., SAunders S. S., Euskirchen E. S., RoBerts D., JAITEH M. S. \& ESSEEN P. A. 2005. Edge influence on forest structure and composition in fragmented landscapes. Conservation Biology 19: 768-782.

HuNDERA K., AERTS R., DE BEENHOUWER M., VAN OVERTVELD K., Helsen K., MuYs B. \& Honnay O. 2013. Both forest fragmentation and coffee cultivation negatively affect epiphytic orchid diversity in Ethiopian moist evergreen Afromontane forests. Biol. Conservation 159: 285-291.

HYLANDER K. 2005. Aspect modifies the magnitude of edge effects on bryophyte growth in boreal forests. J. Appl. Ecol. 42: 518-525.

HYLANDER K. \& EHRLÉN J. 2013. The mechanisms of extinction debts. Trends Ecol. Evol. 28: 341-346.

Hylander K. \& HedDerson T. A. J. 2007. Does the width of isolated ravine forests influence moss and liverwort diversity and composition? - A study of temperate forests in South Africa. Biodiversity and Conservation 16: 1441-1458.

HYLANDER K. \& NEMOMISSA S. 2008. Home garden coffee as a repository of epiphyte biodiversity in Ethiopia. Frontiers in Ecology and the Environment 6: 524-528.

HYLANDER K. \& NEMOMISSA S. 2009. Complementary roles of home gardens and exotic tree plantations as alternative habitats for Ethiopian montane rainforest plant biodiversity. Conservation Biology 23: 400-409.

HYLANDER K., PÓCS T. \& NEMOMISSA S. 2010. Liverworts of Southwestern Ethiopian montane forests: ecological and biogeographical notes. J. Bryol. 32: 92-100. 
Hylander K., Nemomissa S., Delrue J. \& ENKOSA W. 2013. Effects of coffee management on deforestation rates and forest integrity. Conservation Biology 27: 1031-1040.

LAURANCE W. F. 2000. Do edge effects occur over large spatial scales? Trends Ecol. Evol. 15: 134-135.

LÖBEL S., SNÄLl T. \& RYDIN H. 2012. Epiphytic bryophytes near forest edges and on retention trees: reduced growth and reproduction especially in old-growth-forest indicator species. J. Appl. Ecol. 49: 1334-1343.

MoEn J. \& Jonsson B. G. 2003. Edge effects on liverworts and lichens in forest patches in a mosaic of boreal forest and wetland. Conservation Biology 17: 380-388.

MurCIA C. 1995. Edge effects in fragmented forests - implication for conservation. Trends Ecol. Evol. 10: 58-62.

Patiño J., GonzÁlez-Mancebo J. M. \& FernÁndez-PalaCIOS J. M. 2009. Epiphytic bryophytes in Canarian subtropical montane cloud forests: the importance of the time since disturbance and host identity. Canad. J. Forest Res. 39: $48-63$.

Pócs T. 1977. Epiphyllous communities and their distribution in East Africa. Bryophyt. Biblioth. 13: 681-713.

Pócs T. 1996. Epiphyllous liverwort diversity at worldwide level and its threat and conservation. Anales Inst. Biol. Univ. Nac. Autón. México, Bot. 67: 109-127.

Ries L., Fletcher R. J. JR, BATtin J. \& SisK T. D. 2004. Ecological responses to habitat edges: Mechanisms, models, and variability explained. Annual Rev. Ecol. Evol. Syst. 35: 491-522.

SCHMitT C. B. 2006. Montane rainforest with wild Coffea arabica in the Bonga region (SW Ethiopia): plant diversity, wild coffee management and implications for conservation. Ecology and Development Series 47, ZEF Bonn.

SCHMitT C. B., Denich M., DemisSEW S., FRIIS I. \& BOEHMER H. J. 2010. Floristic diversity in fragmented Afromontane rainforests: altitudinal variation and conservation importance. Applied Vegetation Science 13: 291-304.

Silva M. P. P. \& PÔRTO K. C. 2010. Spatial structure of bryophyte communities along an edge-interior gradient in an Atlantic Forest remnant in Northeast Brazil. J. Bryol. 32: $101-112$.

Sonnleitner M., Dullinger S., Wanek W. \& ZechmeISTER H. 2009. Microclimatic patterns correlate with the distribution of epiphyllous bryophytes in a tropical lowland rain forest in Costa Rica. J. Trop. Ecol. 25: 321-330.

TeKetay D., Lemenih M., BeKele T., Yemshaw Y., FeleKe S., Tadesse W., Moges Y., Hunde T. \& Nigussie D. 2010. Forest resources and challenges of sustainable forest management and conservation in Ethiopia. In: F. BONGERS \& T. TENNIGKEIT (eds), Degraded forests in Eastern Africa: management and restoration, pp. 19-64. Earthscan, London.

TscharntKe T., Zeller M., GuHARdja E. \& Bidin A. (eds) 2007. Stability of tropical rainforest margins - linking ecological, economic and social constrains of land use and conservation. Springer, Berlin.

Werner F. A. \& GRAdSTEIN S. R. 2009. Diversity of dry forest epiphytes along a gradient of human disturbance in the tropical Andes. Journal of Vegetation Science 20: 59-68.

ZARTMAN C. E. \& SHAW A. J. 2006. Metapopulation extinction thresholds in rain forest remnants. Amer. Naturalist 167: 177-189.

ZARTMAn C. E. \& NASCimento H. E. M. 2006. Are habitattracking metacommunities dispersal limited? Inferences from abundance-occupancy patterns of epiphylls in Amazonian forest fragments. Biological Conservation 127: 46-54. 